\title{
Quality of life and the health status of elderly persons: a population-based study in the central setão of Ceará
}

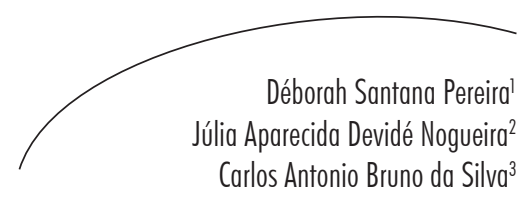

Abstract

Introduction: Healthy aging and quality of life has become a major desire of contemporary society. Understanding the profile of this population will allow the creation of more appropriate policies and actions for the promotion of health and quality of life. Objective: To map aspects related to health and quality of life as perceived by elderly residents of the city of Canindé, in the central sertão region of the state of Ceará. Method: A quantitative, cross-sectional, household-based study was performed. From a population of 5,214 elderly persons, proportional stratified sampling resulted in a sample of 372 individuals. A characterization questionnaire addressing sociodemographic characteristics and health status and the abbreviated version of WHOQOL were used. SPSS version 16.0 was used for descriptive and inferential statistics, adopting a significance level of 5\%. Results: Most elderly individuals were female, married, brown skinned, aged 60 to 69 years old, with an incomplete primary education and an income of up to one minimum wage. Most of the elderly persons had attended 1-3 consultations/admissions in the last 12 months, and reported a high prevalence of hypertension, diabetes, osteoporosis, anxiety and cardiovascular diseases, despite describing their health and quality of life as "good". In terms of quality of life, the psychological domain had the highest, and the environmental domain had the lowest mean score. Conclusions: The prevalent diseases/comorbidities belonged to the chronic non-communicable diseases group. The environmental domain negatively influenced overall quality of life, indicating the importance of environments that provide health promotion and quality of life for elderly people from rural regions.

Key words: Elderly; Quality of Life; Health.

\footnotetext{
Instituto Federal de Educação, Ciência e Tecnologia do Ceará, Campus Juazeiro do Norte, Curso de Educação Física. Juazeiro do Norte, CE, Brasil.

2 Universidade de Brasília, Campus Universitário Darcy Ribeiro, Faculdade de Educação Física. Brasília, DF, Brasil.

3 Universidade de Fortaleza, Centro de Ciências da Saúde, Programa de Pós-graduação em Saúde Coletiva. Fortaleza, CE, Brasil.
}

Correspondence

Déborah Santana Pereira

E-mail: deborahsan@gmail.com 


\section{INTRODUCTION}

Global population aging, caused by falling birth and death rates and an increase in life expectancy, which are the results of countless healthcare advances, is a proven fact. The Instituto Brasileiro de Geografia e Estatística ("the Brazilian Geography and Statistics Institute") (IBGE) ${ }^{1}$ says that Brazil has aged in a rapid and intense manner, and that the majority of elderly persons have a low socioeconomic level and a high prevalence of chronic non-communicable diseases (CNCD), which causes a substantial burden on the national economy, notably through spending on pensions and medical resources.

CNCDs now represent a global health problem, and are the main cause of morbidity and mortality in developing countries such as Brazil. While acknowledging that the development of habits and lifestyles are related in complex ways to social restraints and determinants of health, the behavioral risk factors common to the development of CNCDs are physical inactivity, an unhealthy diet, smoking and alcohol abuse., ${ }^{2,3}$

In this sense, healthy aging is a common desire for modern society. According to Deponti \& Acosta ${ }^{4}$ for a better understanding of the relationship between aging and health, a multidimensional approach should be adopted, considering biological, physical, psychological, economic and social factors. For these authors, it is also important to understand the perception of the elderly individuals themselves about such factors, as they are the main actors in this process.

In a global scenario of demographic, nutritional and epidemiological transition, the term Quality of Life (QOL) has emerged, referring to the maintenance of health in a physical, spiritual, psychological and social context, ${ }^{5}$ and including perceptions of positions in life, levels of dependence, cultural contexts and value systems. ${ }^{6}$

Several factors influence QOL, including health status, family relationships, longevity, disposition, leisure, job satisfaction, salary, pleasure, spirituality, ${ }^{7}$ functional capacity, weakness, disability, ${ }^{8}$ level of physical activity, anthropometric parameters and use of medication. ${ }^{9-11}$ QOL is a broad and subjective term, with different definitions for different authors, that also depends on the influence of individual, social and environmental aspects and perceptions.

With the overall increase in life expectancy, it has been noted that simple longevity is no longer enough to guarantee the happiness of an elderly person, and it also necessary to provide means so that such individuals can pass these years in a satisfactory manner. A long life is no longer the sole aim, with individuals seeking autonomy, social support, health, love and happiness, among other aspects. ${ }^{2,5}$

In this context, QOL among the elderly has been widely studied. With the aim of meeting the needs of society, including health professionals and their patients, QOL and its relationship to health has been heavily used as a means of evaluating the results of certain interventions, ${ }^{12}$ treatments, ${ }^{13}$ programs ${ }^{14}$ and strategies, ${ }^{15}$ involving those of multiple perceptions, settings and parameters.

Faced with the complexity of the issue, studies, indicators and operationally viable instruments have become essential tools for the practice of health professionals working with the elderly population. Similarly, research and population studies on various themes ${ }^{16-18}$ often analyze the structure, composition and form of distribution of certain components, providing, from a broad knowledge of the study population, the possibility of better living conditions.

The sertão (semi-arid, inland region) of the northeast of Brazil is one of the parts of the country where indicators of life quality are most scarce. ${ }^{19}$ In this way, studies such as this contribute greatly with references, useful data and comparative information at both local and regional levels.

Knowing that the analysis of health status and QOL may help to establish the profile of specific 
populations and so create effective intervention targets according to their needs, and being aware of the specificities resulting from environmental, cultural and subjective factors, the present study aimed to map aspects related to health and quality of life from the perception of elderly residents of the city of Canindé, in the central sertão of Ceará.

\section{METHOD}

\section{Study design and location}

A quantitative, cross-sectional, home-based study using primary and objective data was performed. The location defined as the study area was the urban area of the municipal region of Canindé, located in the area known as the central sertão of the state of Ceará, $114 \mathrm{~km}$ from the capital, Fortaleza. Data collection took place between April and June 2013.

\section{Population and sample}

The study population consisted of 5,214 elderly people residing in the urban area of the municipal region of Canindé, Ceará. Proportional stratified sampling achieved a sample of 372 individuals (7.13\% of the total population). The calculation of sample size was made using the formula indicated for finite populations (less than 100,000 units) and considered a level of confidence, chosen for a number of deviations ( $95 \%$, equivalent to two standard deviations); the estimated proportion of the characteristic studied in the overall population (50\%); the estimated proportion of the overall population that does not have the characteristic studied (50\%); population size (5,214 elderly persons) and maximum permissible error (5\%). After calculation of sample size, the proportional size of the strata (city neighborhoods) was determined, ensuring they were represented as accurately as possible, according to their proportion of the population.

Elderly individuals aged 60 or over in the data collection period were included, regardless of gender, provided they were not institutionalized and had resided in the town for at least six months. Elderly persons who were unable to communicate, had a severe neurological condition, used a wheelchair, were morbidly obese or had recently undergone surgery were excluded.

\section{Instruments and procedures}

A closed question questionnaire developed by researchers was used to characterize the sample by sociodemographic characteristics (age, gender, marital status, religion, ethnic background, retirement status, education and income) and health conditions (health perception, health perception compared to peers, presence of diseases, consultations/hospitalizations in the last 12 months, health care system used), and the abbreviated version of the World Health Organization Quality of Life Assessment (WHOQOL-bref) was used to evaluate QOL.

Data collection was conducted through household survey. The elderly were randomly drawn from the streets/avenues and house numbers, in the correct proportion for each district. On every street/avenue houses located on the left and right side were visited alternately. In cases where the selected household had no elderly person who met the inclusion criteria, the next home was immediately selected, alternating from the last house visited, until the entire neighborhood was covered by the sample. When there was more than one elderly person in the same household, the oldest individual was chosen, as such elderly persons are less represented in the population.

Evaluators were trained and instructed regarding the methodological procedures for the selection and the application of the instruments used in the interview, in order to determine parameters of similarity and replicability and avoid possible biases in data collection. All information obtained for the presence/absence of disease was reported only. Completed questionnaires were checked for inconsistencies and then tabulated in a database. 
Data analysis

For data analysis the SPSS (Statistical Packeage for the Social Sciences) software program version 16.0 was used, with the application of the normality test (Kolmogorov-Smirnov) and descriptive (mean, mode, standard deviation and percentages) and inferential (Chi-square test) statistics calculations, according to the variables studied, adopting a significance level of $5 \%(p<0.05)$. The results obtained are shown in tables.

\section{Ethical aspects}

The present study complied with the ethical principles of the Helsinki Declaration, and the study was approved by the Human Research Ethics Committee of the Universidade de Fortaleza ( $\mathrm{n}^{\circ}$ 244.796/2013). The study also complied with Conselho Nacional de Saúde ("National Health Council") (CNS) Resolution 466/2012, which deals with respect for the individual, beneficence and justice, among other themes. ${ }^{20}$ Participants agreed to take part in the study by signing a Free and Informed Consent Form (FICF).

\section{RESULTS}

A total of 372 elderly persons were interviewed, with a mean age of $71.0( \pm 9.2)$ years, a minimum age of 60 years and a maximum age of 96 , and a modal age of 60 . The normality test indicated that the sample was not considered normal $(p=0.00)$.

The sociodemographic characteristics of the elderly persons indicated that most were female $(64.0 \%)$, of mixed race (47.6\%), aged between 60 and 69 years (51.9\%), married (53.5\%) and of the Catholic religion (91.1\%). In terms of education, most reported having an incomplete primary education $(51.9 \%)$, with the next largest group describing themselves as illiterate $(21.0 \%)$. Most said they were retired (84.7\%), with an income of up to one minimum salary $(54.3 \%)$, followed by the group that earned two to four minimum salaries $(40.9 \%)$.

The major diseases or comorbidities reported by the elderly individuals studied, were, in order of prevalence: hypertension (46.2\%), followed by diabetes $(18.0 \%)$, osteoporosis (12.4\%), anxiety $(11.8 \%)$ and cardiovascular disease (10.2\%). It should be noted that the elderly persons could report suffering from more than one condition. At the same time, $25.0 \%$ of elderly individuals said they did not have any diseases and $15.8 \%$ suffered from a condition of lower prevalence, such as arthritis, gastritis, spinal pain and labyrinthitis, rheumatism, asthma, prostrate complications, glaucoma, urinary incontinence, leprosy, spinal disc herniation, gallstones, Parkinson's disease and ulcers.

Following analysis by age intervals, statistically significant differences were found between hypertension $(p=0.01)$, diabetes $(p<0.01)$ and obesity $(p=0.04)$. The frequency of hypertension and diabetes was greater among elderly individuals aged over 80 years. For obesity, this relationship was reversed, with a higher prevalence among the elderly aged 60-69 years; no elderly persons over 80 years old reported being obese. When stratified by gender analysis, statistically significant differences were identified in the prevalence of osteoporosis $(p<0.01)$ and anxiety $(p<0.01)$ among females, compared with males (Table 1). 
Table 1. Prevalence of morbidities by gender and age range. Canindé-CE, 2013.

\begin{tabular}{|c|c|c|c|c|c|c|c|c|}
\hline \multirow[b]{2}{*}{$\begin{array}{l}\text { Diseases/ } \\
\text { morbidities }\end{array}$} & \multicolumn{2}{|c|}{ Gender $\%$} & \multicolumn{5}{|c|}{ Age range (years) $\%$} & \multirow{2}{*}{$\begin{array}{l}\text { Total \% } \\
(\mathrm{n}=372)\end{array}$} \\
\hline & $\begin{array}{c}\text { Male } \\
(\mathrm{n}=134)\end{array}$ & $\begin{array}{l}\text { Female } \\
(\mathrm{n}=238)\end{array}$ & $p$ & $\begin{array}{c}60-69 \\
(\mathrm{n}=193)\end{array}$ & $\begin{array}{c}70-79 \\
(\mathrm{n}=103)\end{array}$ & $\begin{array}{c}\geq 80 \\
(\mathrm{n}=76)\end{array}$ & $p$ & \\
\hline Hypertension & 44.0 & 47.5 & 0.52 & 39.4 & 49.5 & 59.2 & $0.01 *$ & 46.2 \\
\hline Diabetes & 19.4 & 17.2 & 0.60 & 13.5 & 29.1 & 14.5 & $0.00^{*}$ & 18.0 \\
\hline Osteoporosis & 2.2 & 18.1 & $0.00^{*}$ & 10.4 & 13.6 & 15.8 & 0.42 & 12.4 \\
\hline Anxiety & 5.2 & 15.5 & $0.00^{*}$ & 11.9 & 15.5 & 6.6 & 0.18 & 11.8 \\
\hline Cardiovascular & 8.2 & 11.3 & 0.33 & 10.4 & 10.7 & 9.2 & 0.94 & 10.2 \\
\hline Depression & 4.5 & 5.9 & 0.56 & 4.7 & 4.9 & 7.9 & 0.55 & 5.4 \\
\hline Dyslipidemia & 3.0 & 4.6 & 0.44 & 3.1 & 3.9 & 6.6 & 0.42 & 4.0 \\
\hline Pulmonary & 3.0 & 3.4 & 0.84 & 3.1 & 2.9 & 3.9 & 0.92 & 3.2 \\
\hline Obesity & 3.0 & 2.5 & 0.79 & 3.1 & 3.9 & 0.0 & $0.04^{*}$ & 2.7 \\
\hline Thyroid & 0.7 & 3.8 & 0.08 & 3.6 & 2.9 & 0.0 & 0.25 & 2.7 \\
\hline Cancer & 0.7 & 0.4 & 0.68 & 0.5 & 0.0 & 1.3 & 0.49 & 0.5 \\
\hline None & 31.3 & 21.4 & $0.03^{*}$ & 28.5 & 21.4 & 21.1 & 0.27 & 25.0 \\
\hline
\end{tabular}

${ }^{*} p<0.05$ by the Chi-squared test.

Depending on the disease or comorbidities, most elderly persons $(46.5 \%)$ reported the occurrence of one to three consultations or hospitalizations in the preceding 12 months, followed by $33.3 \%$ of elderly individuals who reported having attended four to six consultations or hospitalizations in this period, while $15.1 \%$ said they had not had either a consultation or a hospitalization. No significant differences were found $(p=0.72)$ for distribution by gender, but when analyzed by age group, it was found that the frequency of such procedures tended to increase significantly ( $\mathrm{p}<0.01)$ among older elderly persons.

When asked about the healthcare system they used for such consultations/hospitalizations, 84.1\% answered the Sistema Único de Saúde ("Unified Health System") (SUS) and only 15.9\% said they used supplemental healthcare. It is worth noting that elderly persons with a private or supplementary healthcare plan may also use SUS services in some way.

Overall, the majority of the elderly perceived their health (76.3\%) and QOL (45.7\%) as good, with no significant differences between gender and age for these two variables. By comparing their health with other elderly persons, most saw it as "similar" (47.3\%) and "better" (47.0\%), with significant differences in analysis stratified by gender and age group ( $p=0.01$ ), with women and younger elderly persons having better health than their peers.

In terms of QOL, the mean (standard deviation) of the scores obtained in the four domains and overall is shown in Table 2. It can be seen that the psychological health and social relationships domains are positive aspects of QOL, while the environment domain had the lowest mean value among this population. 


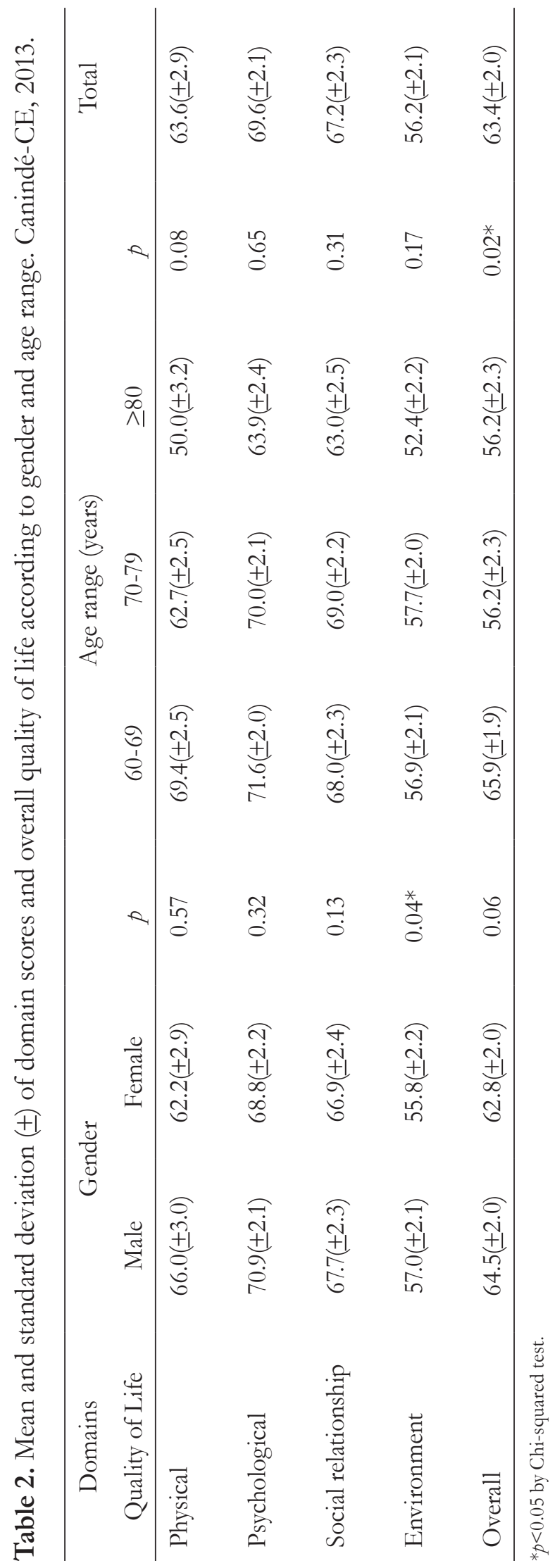


Of the facets of the WHOQOL-bref, those that stood out has having the highest (mean) values were: negative feelings (79.2 \pm 0.8 ), personal relationships $(77.6 \pm 0.7)$, personal support (77.7 \pm 0.7$)$, self-esteem $(74.5 \pm 0.7)$, spirituality/ religion/personal beliefs $(74.1 \pm 0.7)$ and body image and appearance (72.2 \pm 0.8$)$. Those with the lowest (mean) values were: recreation and leisure (39.9 \pm 1.0$)$, financial resources $(49.8 \pm 0.9)$, sexual activity $(51.4 \pm 0.8)$, positive feelings $(53.7 \pm 0.9)$ and

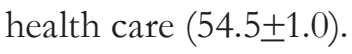

When analyzing the QOL results by gender it was observed that QOL among women was lower than that of men in general and for all the domains, but was only statistically significant in the domain of environment ( $p=0.04)$. In terms of age, it can be seen that the overall QOL and all its domains tend to decrease as age increases, with such an decrease being statistically significant once again in the environment domain $(p=0.02)$. No statistically significant differences were found between overall QOL and its domains separated by ethnic background, religion, marital status, education and income (table 3). 


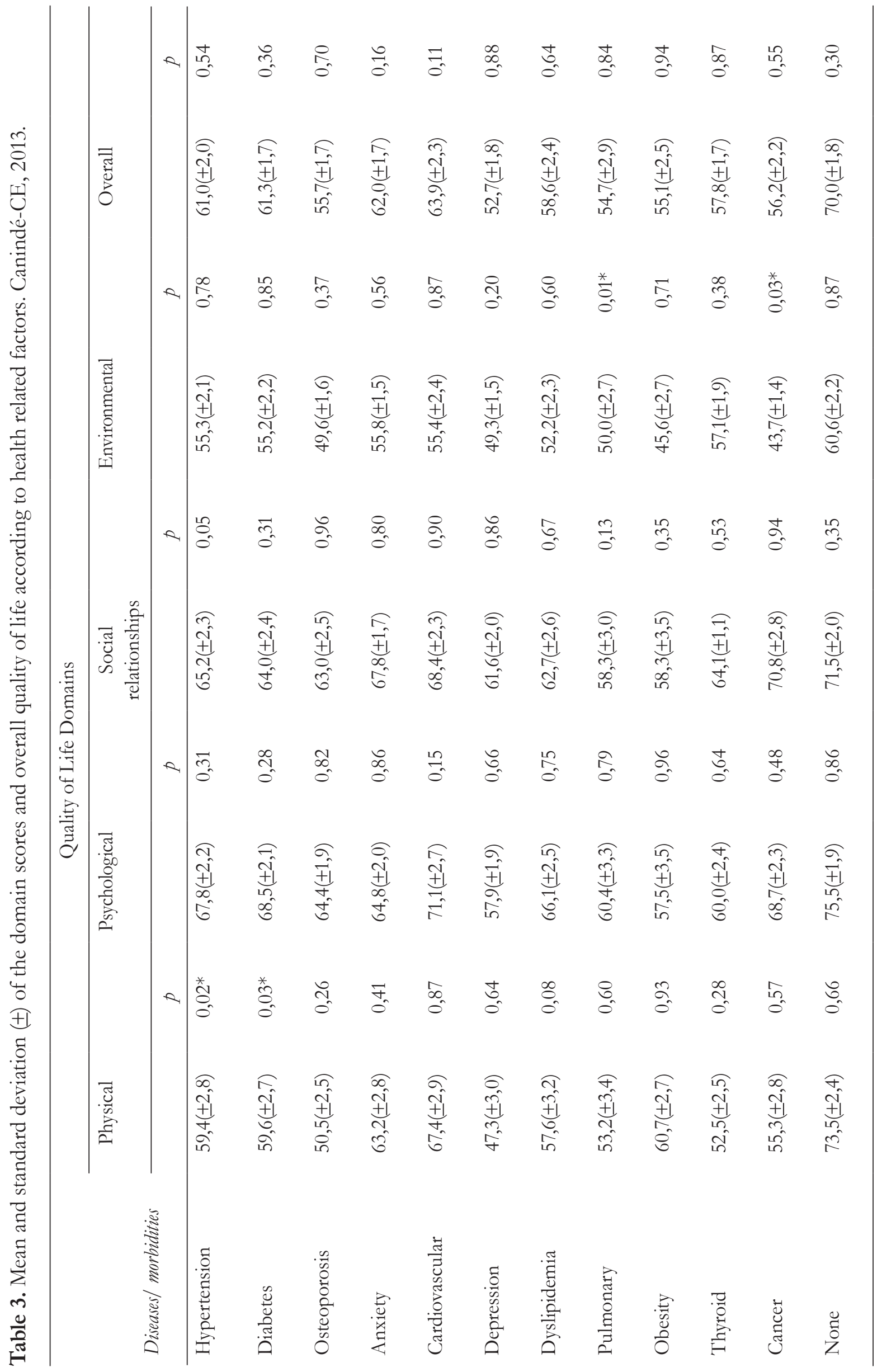




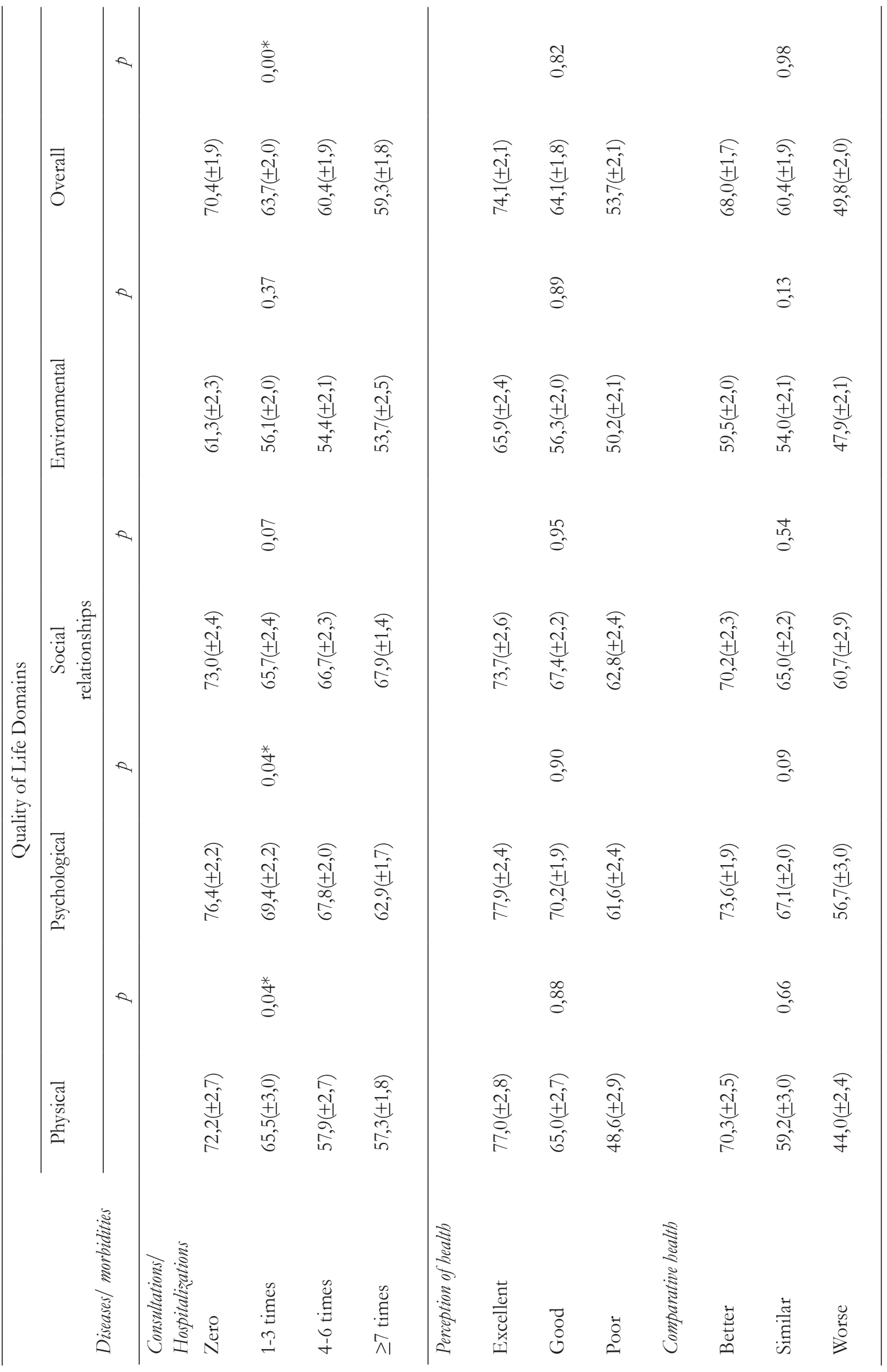




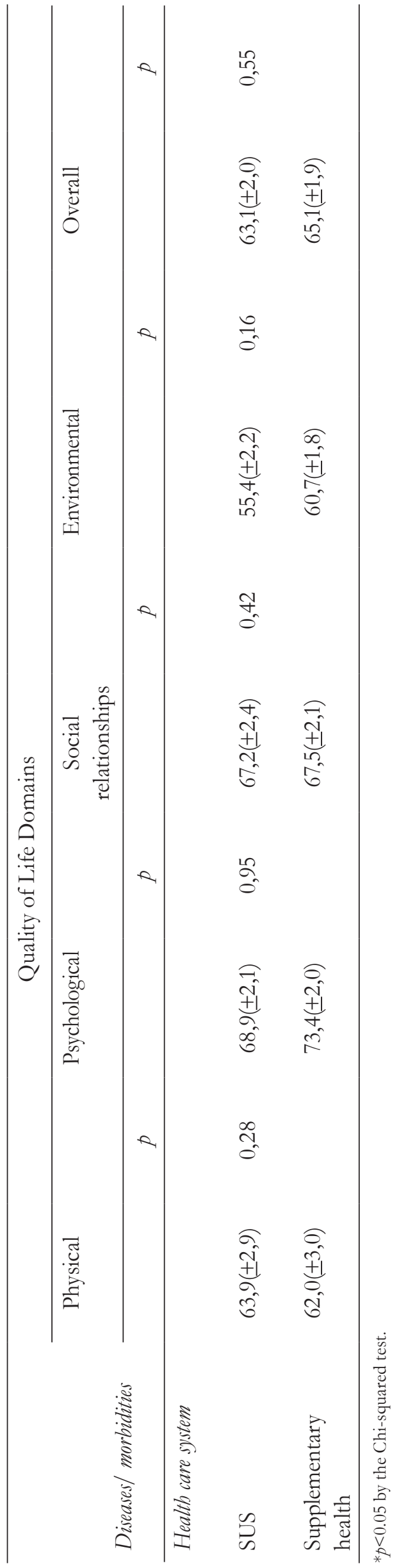


In terms of QOL domains separated according to diseases/morbidity, significant differences were found between the physical health domain and the presence of hypertension $(p=0.02)$ and diabetes $(p=0.03)$ and also between the environment domain and pulmonary disease $(p=0.01)$ and cancer $(p=0.03)$. While the other variables did not present statistically significant differences, major differences were observed in QOL values due to the presence of some diseases.

As for other aspects related to health, the variable that showed the greatest association with the QOL of the elderly was the number of medical consultations/hospitalizations in the previous 12 months. Said association was statistically significant for the physical health $(p=0.04)$, psychological health $(p=0.04)$ and overall QOL $(p=0.00)$ domains.

\section{DISCUSSION}

The present study revealed a predominance of specific population characteristics that were extremely similar to another study, ${ }^{16}$ performed with 385 elderly persons in the urban area of Quixadá, a town also located in the central region of the state of Ceará, which described a predominance of women (64.3\%), participants aged between 60 and 69 years $(41.0 \%)$, who were married (56.0\%), had an incomplete primary level education $(54.4 \%)$, did not perform paid work $(84.1 \%)$ and had an income of up to one minimum salary $(55.1 \%)$. Considering the location of the towns, the size of the populations and the samples, a certain uniformity with other urban areas in the central sertão of Ceará may be supposed.

In seeking comparisons with other regions of the country, a study ${ }^{21}$ performed in the district of Ermelino Matarazzo, located in the western part of the state of São Paulo was found. This study comprised a sample of 385 elderly persons, the majority of whom were female $(60.5 \%)$, aged between 60 and 74 years (57.1\%), Caucasian (55.5\%), single, divorced or widowed $(54.2 \%)$, did not perform paid work $(78.4 \%)$ and had an incomplete primary level education (47.6\%). In another study ${ }^{17}$ of 1,705 elderly persons in Florianópolis, in the state of Santa Catarina, the majority of participants were women (63.9\%), Caucasian (86.0\%), married or lived with a partner $(58.8 \%)$, aged between 60 and 69 years $(51.1 \%)$, with a low level of schooling $(40.0 \%)$ and an income of up to one minimum salary $(25.2 \%)$ or between one and two minimum salaries $(25.0 \%)$.

It can be seen that while there are similarities among some variables, not all the data in these studies agrees with the present study. Among the similarities found between the studies in the states of Ceará ${ }^{16}$ and São Paulo, ${ }^{21}$ the low levels of education and income stand out, despite the states having different characteristics. In Santa Catarina,${ }^{17}$ the educational level was low, but the income reported was slightly higher.

The sertão of the north east of Brazil, compared to other regions of the country, is marked by inequality in its development and great contrasts. Irregular rainfall and intermittent drought have a major social, political and economic influence. ${ }^{22}$ Covering a large part of the northeast of Brazil, the Ceará sertão is affected by demographic and epidemiological transition. In this region, the main cause of death in the population is cardiovascular disease, especially among men, among whom there is a clear increase in cerebrovascular illness. ${ }^{19}$

Some of the specific characteristics of Canindé$\mathrm{CE}$, where the present study was performed, is that religious tourism is one of the main sources of income for the urban areas of the town, which also has one of the largest concentrations of land reform settlements in Brazil. ${ }^{23}$ Such factors have an influence on the social, economic and environmental characteristics of the area, factors that can reflect on the health situation and QOL of the population. For example, the fact that Canindé$\mathrm{CE}$ is an important religious center in the region helps to understand the influence of spirituality in the QOL found in the present study, and the presence of the settlements helps to explain the low educational level.

As health and QOL are broad, complex constructs that are hard to measure, it is noted here that the presence of some aspects is capable of merely indicating the health situation and QOL of individuals, without going as far as "classifying" 
the same. As such, the present study considered the existence of diseases/comorbidities, the frequency of recent consultations and/or hospitalizations, access to health care and perception of health and QOL compared with peers as indicators of the health status and QOL of this population.

The presence of certain diseases is a contributing factor to increased frailty among the elderly and may have a negative effect on their QOL. ${ }^{24}$ In the elderly persons studied, hypertension was most prevalent, especially among individuals of a more advanced age, followed by a high prevalence of diabetes, osteoporosis, anxiety and other cardiovascular diseases.

Among elderly persons from another town in the Ceará sertão, Quixadá, the most frequent morbidities were hypertension, diabetes and dyslipidemia. ${ }^{16}$ Among elderly persons from a city in São Paulo, Campinas, hypertension, circulation problems and osteoarticular problems were most prevalent. ${ }^{18}$ A study ${ }^{25}$ of elderly persons from Santa Catarina found that the most prevalent diseases were hypertension, osteoarticular disease and hypercholesterolemia, with heart disease and diabetes standing out among the male members of the group.

It thus appears that the CNCDs represent the main type of disease found among the elderly in different regions of Brazil, including in the regions of the sertão, which are historically less developed than the center and south of the country, and face problems such as hunger and communicable diseases. Among the CNCDs, cardiovascular disease is the leading cause of death and generates the highest costs from hospitalizations to the Brazilian health system, especially affecting middle-aged and older adults. ${ }^{3}$

Most of the elderly persons studied reported that the health care service they used most was the SUS, and said they had undergone a consultation/ hospitalization in the previous year, with a higher prevalence among females and older elderly persons, which may indicate a degree of frailty and/ or be indicative of the level of curative/preventive care among these groups.
Literature describes a significant male invisibility in the primary health care services, pointing to the possible lack of investment in the organization of the service in terms of gender, so that there is little supply of specialized services and a limited understanding of the symbolic and cultural factors involved in the male reality. ${ }^{26}$

Elderly men also have a high prevalence of behaviors considered harmful to health, such as smoking, alcohol and poor diet, which affect social interaction and compromise quality of life, indicating a need for health actions and the need for policies of prevention and intervention. ${ }^{27}$

A study ${ }^{24}$ conducted in Santa Catarina also reported that the majority of elderly persons $(37.7 \%)$ reported two to three medical appointments and $(81.0 \%)$ no hospitalization in the last 12 months. The authors found that the greatest frailty (repeated hospitalization) was associated with the presence of a range of health problems, polypharmacy and the use of antibiotics in the previous month. This finding corroborates the correlation between the number of consultations/hospitalizations and QOL, contributing to the understanding of the influence of this variable on the elderly of the present study.

It is also possible that the associations found between QOL and certain diseases in the present study are dependent on the amount and continuous use of medicines needed for their treatment and its side effects, along with the negative effects of the diseases themselves. In this respect, it is emphasized that in addition to the use of drugs, other measures are recommended to help with the treatment of CNCDs, such as physical activity and diet, which can contribute to an improvement in QOL. ${ }^{23}$ STOP

For example, even though high blood pressure is considered a polygenic syndrome with genetic influence, recent meta-analysis studies have shown that regular physical activity can act as a reducing agent for blood pressure, even allowing a reduction in dosages of antihypertensive drugs in some cases. ${ }^{23}$ 
In terms of overall QOL, the mean value found in the present study was below that found among elderly persons in Porto Alegre-RS, ${ }^{28}$ both for institutionalized elderly persons (69.83), and the community in general (69.81). These results reinforce the importance of seeking an improvement in the QOL of the elderly persons interviewed.

When analyzing QOL domains, the mean of the scores revealed that the psychological health domain was the most influential factor, and the environment domain was the least influential factor on overall QOL score. It is therefore important to understand environmental factors not only through natural and built structures, but also through geographical location, security, access to facilities, venues and the travel time required to reach them, equipment, its maintenance and aspects of socialization, all of which are factors that have a great influence on QOL and collective and individual lifestyle. ${ }^{17}$

It is possible to say that, in general, a number of factors have threatened the health and QOL of urban populations in Brazil, such as unemployment, air pollution, environmental depredation, and ineffective urban transport. ${ }^{29}$ In order to reverse this situation the author of the present study ${ }^{29}$ has pointed out the effectiveness of the "healthy cities" strategy, together with a rationalization of resources and project development through an inter-sectoral approach, involving different government agencies and the various sectors of local society.

A study comparing elderly people living alone with those living with their families and with institutionalized elderly people ${ }^{30}$ showed that all had regular levels of QOL. However, the physical bealth domain showed statistically significant differences between elderly persons living with their families and institutionalized elderly people, with the latter group more satisfied.

Another study ${ }^{31}$ involving groups of younger (60-70 years) and very old (85 years or more) elderly people, found that the QOL in both groups was considered good, suggesting that QOL does not tend to decrease with advancing age. However, the results of the present study found that elderly persons aged between 60 and 69 had a higher QOL than those aged 70 years or more.

Upon analyzing these findings more specifically, one can identify the influence of certain facets on the overall QOL of the elderly respondents. Those with the highest values were negative feelings, personal relationships, social support, self-esteem and spirituality/religion/personal beliefs. The lowest values were for recreation and leisure, financial resources and sexual activity.

It is known that the inclusion of leisure in social work with the elderly is responsible for generating better self-esteem, socialization, forms of social contact and voluntary learning, which may favor the QOL. However, a common misconception is to think of this as an autonomous process, detached from social conditioning and the relations of production, and thus that the individual is the only person responsible for the activity. ${ }^{32}$

In terms of financial resources, another study $y^{33}$ also points out the strong relationship between economic issues and QOL and health in old age, indicating that many elderly people with a low socioeconomic status have a high prevalence of CNCTs, and less access to goods and services.

In terms of the sexual health of the people involved in the study, most attached great importance to sexuality, manifested in the form of affection, touching and companionship. However, prejudice regarding this subject still exists among part of society and even health professionals themselves, a fact that is reflected in the scarcity of studies addressing the topic. ${ }^{34}$

In summary, several studies ${ }^{8-11}$ point to the influence of individual, social and environmental factors on health and QOL, such as level of physical activity, anthropometric parameters, use of medications, functional capacity, weakness, disability, health status, family relationships, job satisfaction, leisure, mood, longevity, pleasure and spirituality. Knowledge of both the health levels and the QOL of the elderly is important to understanding the naturally more vulnerable reality of this population group, and can help to 
minimize the demands on health services and assist in developing strategies to improve the situation. ${ }^{35}$

It is important to note that although this study is representative of the studied population and relevant in terms of recording indicators of health and the life of older people living in the central sertão of the northeast, a region that is historically neglected, it has some limitations. Among these are the cross-sectional design, which precludes the establishment of a cause and effect relationship between health status and QOL, and the use of information reported by the elderly without the measurement of the variables or diagnostics of these pathologies.

\section{CONCLUSION}

The present study identified a profile of elderly persons that was similar to those found in other towns of the central sertão of Ceará and allowed some regional differences among this population to be explained. In agreement with other studies, it was found that the most prevalent diseases/ comorbidities were non-communicable chronic diseases, and that these, as well as resulting in the largest number of consultations/hospitalizations, affect older elderly people.

Greater fragility among the elderly, the perception of having a poor quality of life and the natural process of reduction of vitality was related to the environment domain. This result indicates the importance of considering environment as something that promotes not only longevity, but also the health and quality of life of this population. In addition, differences between the genders highlight the importance of studies that help to understand the aging process and illness experienced by males.

The facets that positively influenced the quality of life were personal relationships, support and social support, self-esteem and spirituality, while those with a negative effect were in the sexual health and emotional facets, indicating that society and services, especially those related to health, must not neglect the feelings and significance of life in this population, if they are to effectively develop comprehensive health care. Given the above, it highlights the importance of health promotion actions that aim to modify the determinants and conditioning of how illness develops and the negative perception of the quality of life of elderly persons of the central sertão of Ceará.

\section{ACKNOWLEDGEMENTS}

The authors would like to thank the students and professors of the Instituto Federal de Educação, Ciência e Tecnologia of Ceará-IFCE, Campus Canindé, who supported and contributed to the data collection of this work.

\section{REFERENCES}

1. Instituto Brasileiro de Geografia e Estatística. Projeção da população do Brasil por sexo e idade para o período 1980-2050: revisão 2008. Rio de Janeiro: IBGE; 2008.

2. Brasil. Ministério da Saúde, Secretaria de Atenção a Saúde. Política Nacional de Promoção da Saúde. 3.ed. Brasília, DF: Ministério da Saúde, 2010.

3. Schmidt MI, Ducan BB, Silva GA, Menezes AM, Monteiro CA, Barreto SM. Doenças crônicas não transmissíveis no Brasil: carga e desafios atuais. Lancet [Internet] 2011 [acesso em 15 fev 2014]:6174. Disponível em http://download.thelancet.com/ flatcontentassets/pdfs/brazil/brazilpor4.pdf
4. Deponti RN, Acosta MAF. Compreensão dos idosos sobre os fatores que influenciam no envelhecimento saudável. Estud Interdiscip Envelhec 2010;15(1):31-50.

5. Organização Mundial de Saúde. Principios de las naciones unidas a favor de las personas de edad: resolución 46/91. Genebra: OMS; 1991.

6. The WHOQOL Group. The World Health Organization Quality of Life Assessment (WHOQOL): position paper from the World Health Organization. Soc Sci Med [Internet] 1995 [acesso em 19 nov 2012];41(10):1403-9. Disponível em: http:// www.ncbi.nlm.nih.gov/pubmed/8560308 
7. Nahas MV. Atividade física, saúde e qualidade de vida: conceitos e sugestões para um estilo de vida ativo. 5.ed. Londrina: Midiograf, 2010.

8. Barbote E, Guillemin F, Chau N, Lorhandicap Group. Prevalence of impairments, disabilities, handicaps and quality of life in the general population: a review of recent literature. Bull World Health Organ 2011;79(11):1047-55.

9. Ferreira EEDBA. Gestão de custos com medicamentos, hidroginástica e qualidade de vida em pessoas idosas de Santarém [Dissertação]. Coimbra: Universidade de Coimbra, Faculdade de Ciências do Desporto e Educação Física; 2011.

10. Gomes Neto M, De Castro MF. Estudo comparativo da independência funcional e qualidade de vida entre idosos ativos e sedentários. Rev Bras Med Esporte. 2012;18(4):234-7.

11. Silva RS, Silva I, Silva RA, Souza L, Tomasi E. Atividade física e qualidade de vida. Ciênc Saúde Coletiva 2010;15(1):115-20.

12. Santos CAS, Dantas EEM, Moreira MHR. Correlation of physical aptitude; functional capacity, corporal balance and quality of life (QoL) among elderly women submitted to a post-menopausal physical activities program. Arch Gerontol Geriatr 2011;53(3):344-9.

13. Li R, Yan BP, Dong M, Zhang Q, Yip GWK, Chan $\mathrm{CP}$, et al. Quality of life after percutaneous coronary intervention in the elderly with acute coronary syndrome. Int J Cardiol 2012;155(1):90-6.

14. Fernández-prado S, Conlon S, Mayán-Santos JM, Gandoy-Crego M. The influence of a cognitive stimulation program on the quality of life perception among the elderly. Arch Gerontol Geriatr 2012;54(1):181-4.

15. Olsson IN, Runnamo R, Engfeldt P. Drug treatment in the elderly: an intervention in primary care to enhance prescription quality and quality of life. Scand J Prim Health Care 2012;30(1):3-9.

16. Silva GDOB, Gondim APS, Monteiro MP, Frotal MA, Meseses ALL. Uso de medicamentos contínuos e fatores associados em idosos de Quixadá, Ceará. Rev Bras Epidemiol 2012;15(2):386-95.

17. Giehl MWC, Schneider IJC, Corseuil HX, Benedetti TRB, D’Orsi E. Atividade física e percepção do ambiente em idosos: estudo populacional em Florianópolis. Rev Saúde Pública 2012;46(3):516-25.

18. De Oliveira MA, Francisco PMSB, Costa KS, Barros MBA. Automedicação em idosos residentes em Campinas, São Paulo, Brasil: prevalência e fatores associados. Cad Saúde Pública 2012;28(2):335-45
19. Santos JP, Paes NA. Envelhecimento demográfico e fatores explicativos da mortalidade dos homens idosos da região Nordeste do Brasil [Internet]. In: $29^{\circ}$ Congreso de La Asociación Latinoamericana de Sociologia; 2013; Santiago. Santiago: ALAS; 2013 [acesso em 20 jan 2014]. Disponível em: http:// actacientifica.servicioit.cl/biblioteca/gt/GT9/GT9_ PereiraJAntunesN.pdf

20. Brasil. Conselho Nacional de Saúde. Resolução no 466, de 12 dezembro de 2012. Diretrizes e normas regulamentadoras de pesquisas envolvendo seres humanos. Brasília: Conselho Nacional de Saúde; 2013. Disponível em: http://conselho.saude.gov.br/ resolucoes/2012/Reso466.pdf

21. Salvador EP, Reis RS, Florindo AA. A prática de caminhada como forma de deslocamento e sua associação com a percepção do ambiente em idosos. Rev Bras Ativ Fís Saúde 2012;14(3):197-205.

22. Morrison CEF. A seca, o semi-árido e o pequeno agricultor em Canindé, Ceará. In: Taddei R, Gamboggi AL, organizadores. Depois que a chuva não veio: respostas sociais às secas no Nordeste, na Amazônia e no Sul do Brasil. Fortaleza: FUNCEME/ CIFAS; 2010. p.137-175.

23. Rondon M, Brum PC. Exercício físico como tratamento não farmacológico da hipertensão arterial. Rev Bras Hipertens 2003;10(2):134-9.

24. De Araújo PL, Galato D. Risco de fragilização e uso de medicamentos em idosos residentes em uma localidade do sul de Santa Catarina. Rev Bras Geriatr Gerontol 2012;15(1):119-26.

25. Virtuoso JF, Mazo GZ, Menezes EC, Cardoso AS, Dias RG, Balbé GP. Perfil de morbidade referida e padrão de acesso a serviços de saúde por idosos praticantes de atividade física. Ciênc Saúde Coletiva 2012;17(1):23-31.

26. Gomes R, Moreira MCN, Nascimento EF, Rebello LEFS, Couto MT, Schraiber LB. Os homens não vem! Ausência/invisibilidade masculina na atenção primária. Ciênc Saúde Coletiva [Internet] 2011 [acesso em 15 jan 2014];16(1):983-92.

27. Senger AEV, Ely LS, Gandolfi T, Schneider RH, Gomes I, Carli GA. Alcoolismo e tabagismo em idosos: relação com ingestão alimentar e aspectos socioeconômicos. Rev Bras Geriatr Gerontol 2011;14(4):713-9.

28. Vitorino LM, Paskulin LMG, Vianna LAC. Qualidade de vida de idosos da comunidade e de instituições de longa permanência: estudo comparativo. Rev Latinoam Enferm 2013;21(n. esp):3-11.

29. Westphal MF. O modelo de atenção na perspectiva de saúde integral: a promoção de saúde e a estratégia de “municípios saudáveis”. Sanare 2000;2(3):1-6. 
30. Dias DSG, Carvalho CS, De Araújo CV. Comparação da percepção subjetiva de qualidade de vida e bemestar de idosos que vivem sozinhos, com a família e institucionalizados. Rev Bras Geriatr Gerontol 2013;16(1):127-38.

31. Maués CR, Paschoal SMP, Jaluul O, França CC, Jacob Filho W. Avaliação da Qualidade de vida: comparação entre idosos jovens e muito idosos. Rev Bras Clín Med 2010;5(8):405-10.

32. Teixeira SM. Lazer e tempo livre na "terceira idade" potencialidades e limites no trabalho social com idosos. Rev Kairós 2010;10(2):169-88.
33. Neri MC, Soares WL. Estimado o impacto da renda na saúde através de programas de transferência de renda aos idosos de baixa renda no Brasil. Cad Saúde Pública 2007;23(8):1845-56.

34. Bastos CC, Closs VE, Pereira AMVB, Batista C, Idalêncio FA, Carli GA, et al. Importância atribuída ao sexo por idosos do município de Porto Alegre e associação com a autopercepção de saúde e o sentimento de felicidade. Rev Bras Geriatr Gerontol 2012;15(1):87-95.

35. Lima MJB, Portela MC. Elaboração e avaliação da confiabilidade de um instrumento para medição da qualidade de vida relacionada à saúde de idosos independentes. Cad Saúde Pública 2010;26(8):1651-62.

Received: June 26, 2014

Revised: April 6, 2015

Accepted: August 18, 2015 